\title{
DESCRIPTIVE EPIDEMIOLOGY OF STEPHANOFILARIASIS (HUMPSORE) IN CATTLE
}

\author{
M. Akter ${ }^{1}$, M. K. Hassan ${ }^{1}$, M. Ahammed ${ }^{2}$, M. A. Ali $^{3}$, G. C. Biswas ${ }^{4}$, M. T. Islam ${ }^{1}$ and M. A. Ehsan ${ }^{1 *}$ \\ ${ }^{1}$ Department of Medicine; ${ }^{2}$ Department of Pharmacology, Faculty of Veterinary Science, Bangladesh \\ Agricultural University, Mymensingh-2202; ${ }^{3}$ Deaprtment of Pathology and Parasitology, Jhenaidah Govt. \\ Veterinary College, Jhenaidah; ${ }^{4}$ Deaprtment of Physiology, Faculty of Veterinary Science, Bangladesh \\ Agricultural University, Mymensingh-2202, Bangladesh
}

\begin{abstract}
An epidemiological study was conducted to investigate the epidemiology of humpsore (stephanofilariasis) infection on cattle of different age and sex by collecting information from samples conveniently from different areas of Mymensingh district in Bangladesh. Clinical history and direct examination is done to detect the infection. Out of 503 samples total $43.14 \%$ cattle were found stephanofilariasis positive. The prevalence of stephanofilariasis was higher (27.24\%) in cattle between 5-10 years old cattle than of less than 5 years $(10.93 \%)$ and more than 10 years $(4.97 \%)$ old cattle. Females have shown more positive $(36.98 \%)$ result than male (male entire $=3.18 \%$, male castrated $=2.98 \%)$ that was $6.16 \%($ Odds ratio $=1 ; \mathrm{P}$ value $=$ $0.987, \chi^{2}=0.003$ ). Local breed shown $36.98 \%$ positive to stephanofilariasis followed in descending order by $2.98 \%$ in Red Sindhi, $0.99 \%$ in Sahiwal, $0.80 \%$ in Jersey cross, $0.40 \%$ in Holstein cross, Haryana and Red Chittagong breeds and $0.20 \%$ in Pabna breed. From the study it is shown that highest (14.1\%) prevalence found in the location of neck region of local breed $(12.72 \%)$ in female cattle $(12.52 \%)$ and in the age group of 5-10years $(9.74 \%)$ than other category on the basis of location of lesions.
\end{abstract}

Key words: Humpsore, Stephanofilariasis, Cattle, Flies

INTRODUCTION

Livestock constitute an important part of the wealth of a country, since in addition to draft power and leather, it provides manure, meat and milk to the vast majority of the people (Banglapedia, 2015). Current contribution of livestock sub-sector to overall GDP is about 1.78\% (Bangladesh Economic Review, 2014). Skin of cattle is often affected by stephanofilarial infection in the Indian subcontinent and is commonly known as 'Humpsore' (Singh et al., 2014; Subha, 2013) as in Bangladesh. Humpsore or stephanofilariasis is one of the important diseases causes serious leather defect. The disease is prevalent and wide spread $(2.5 \%$ of the cattle population being affected) in Bangladesh, (Ibrahim et al., 2013).Humpsore is prevalent almost in all seasons of the year but aggravated in the summer and rainy season due to high temperature and high humidity which favors tremendous growth of fly vectors (Baki, 1995).

Stephanofilariasis infections in the skin, damage the hair follicles and skin glands and cause dermatitis. Severe infections can considerably stress affected animals. Humpsore can be particularly annoying for dairy cattle and in endemic regions it may considerably hamper manual or mechanical milking, and make it impossible to comply with hygienic measures for milking. Damaged hides can be downgraded and even rejected at slaughter (Junquera, 2015). The main objective of present study was to investigate the epidemiological distribution of humpsore in cattle.

\section{MATERIALS AND METHODS}

\section{Sampling strategy}

The research work was conducted in different areas of Mymensingh district during the period from January 2016 to May 2016. A cross-sectional study was conducted on a total of 503 cattle belonging to the Bangladesh Agricultural University (BAU) Dairy Farm, BAU Agronomy Farm, BAU Artificial Insemination Centre and 3 villages such as Shikarikandha, Churkhai and Sutiakhali around the BAU campus were examined for stephanofilarial lesions of different breed, sex, age, and the presence and location of presumed stephanofilarial lesions were recorded for each animal conveniently from different area of Mymensingh district.

*Corresponding e-mail address: maehsan2003@gmail.com 


\section{Akter and others}

\section{Diagnosis of disease}

The diagnosis of the disease was based on the epidemiological data, history of draft use and clinical examination of the lesions. The lesions of humpsore were detected by distant and as well as close inspection techniques of physical examination. Presence of extreme irritation, evidence of rubbing, crusts, and crumbly scab which may crack to expose blood-stained fluid were the clinical findings to confirm the presumptive diagnosis.

\section{Classification of lesions}

Clinically two types of lesions were considered for descriptive as well as diagnostic purposes (Nooruddin, et al., 1985). Early lesions were smaller in size (about 3 to $4 \mathrm{~cm}$ in diameter) characterized by formation of thin, mildly granular crusts in most lesions and rarely laminated. The old lesions, on the other hand, were larger in size and had coarsely granular crusts with many cracks and crevices with or without centrally located ulcer. Both types were partially or completely hairless. These lesions were again classified according to severity depending on amount of crusts, exudation, size of lesion, ulceration into 3 types-mild, moderate and severe.

\section{Examination of environment}

During examination of animals, examination of the environment was also done for other chances of injury beside draft use which include lacrimation, rope sore, burn, horn rack, stanchion, neck chain, tree, wall, manger and licking.

\section{Method of aging}

Age of the animals and the duration of draft use were recorded according to the comments of the owners of the animal. For the convenient of analysis, animals were classified into adolescent male or female up to 3 years of age, cow, bullock and bull.

\section{Statistical methods}

Chi-square test was performed to assess the associations of the stephanofilarial lesions with the demographic variables such as age, breed, gender, type and class of animal (Everritt, 1992). Percentage value was calculated to estimate the prevalence of humpsore (stephanofilariasis) and the bivariable analysis was done to find out the significant association between exposure and outcome variable. All analysis were done by using Epiinfo ${ }^{\mathrm{TM}} 7.1 .5$ version (https://www.cdc.gov/epiinfo/index.html).

\section{RESULTS AND DISCUSSION}

In current study the overall prevalence $(43.14 \%)$ is higher than the earlier reports (Nooruddin, et al., 1986) which is compared in our result due to higher use of animal in draft purpose, higher prevalence of other chances of injury and relatively small size of sample. In this study it is found that the prevalence is high $(63.1 \%)$ in the age group of 5-10 years old than others whereas scientist found the prevalence increases with age until 4-5 years and then decreases for almost zero to ten years (Roy and Misra, 1989; Fadzil, 1977; Agrawal and Shah, 1984).

In this study it is found that females $(85.7 \%)$ have more prone to affect in humpsore than male $(14.3 \%)$; whereas Johnson et al., (1986) stated that males are generally more affected than female cattle. In another study in West Bengal, males had a prevalence rate of $17.34 \%$ and $14.03 \%$ of females (Roy and Misra, 1990). 
Descriptive epidemiology of stephanofilariasis in cattle Table 1. Prevalence of humpsore (stephanofilariasis) in cattle in Mymensingh

\begin{tabular}{|c|c|c|c|c|}
\hline \multicolumn{2}{|r|}{ Variables } & No. of cattle examined & No. of cattle affected & Prevalence $(\%)$ \\
\hline \multirow{6}{*}{ Study Areas } & Agronomy farm & 6 & 6 & 100.00 \\
\hline & AI center & 10 & 6 & 60.00 \\
\hline & BAU Dairy farm & 84 & 28 & 33.33 \\
\hline & Churkhai & 100 & 45 & 45.00 \\
\hline & Shikarikanda & 98 & 33 & 33.67 \\
\hline & Sutiakhali & 205 & 99 & 48.29 \\
\hline \multirow{8}{*}{ Breed } & Local & 424 & 186 & 43.87 \\
\hline & Red sindhi & 23 & 15 & 65.22 \\
\hline & Sahiwal & 20 & 5 & 25.00 \\
\hline & Holstein Cross & 9 & 2 & 22.22 \\
\hline & Jersy Cross & 10 & 4 & 40.00 \\
\hline & Hariana & 2 & 2 & 100.00 \\
\hline & Pabna & 2 & 1 & 50.00 \\
\hline & Red Chittagong & 13 & 2 & 15.38 \\
\hline \multirow{4}{*}{ Class } & Heifer & 116 & 16 & 13.79 \\
\hline & Cow & 309 & 168 & 54.37 \\
\hline & Bull & 57 & 17 & 29.82 \\
\hline & Bullock & 21 & 16 & 76.19 \\
\hline \multirow{3}{*}{ Gender } & Male Entire & 55 & 16 & 29.09 \\
\hline & Male Castrated & 17 & 15 & 88.24 \\
\hline & Female & 431 & 186 & 43.16 \\
\hline \multirow{3}{*}{ Age } & Upto 5 yrs & 242 & 55 & 22.73 \\
\hline & $5-10$ yrs & 230 & 137 & 59.57 \\
\hline & More than $10 \mathrm{yrs}$ & 31 & 25 & 80.65 \\
\hline \multirow{3}{*}{$\begin{array}{c}\text { Used for } \\
\text { ploughing }\end{array}$} & Yes & 141 & 119 & 84.40 \\
\hline & No & 362 & 98 & 27.07 \\
\hline & Overall & 503 & 217 & $43.14 \%$ \\
\hline
\end{tabular}

Table 2. Risk factors analysis of humpsore (stephanofilariasis) in cattle in Mymensingh

\begin{tabular}{|c|c|c|c|c|c|}
\hline & \multirow{2}{*}{ Risk factors } & \multicolumn{2}{|c|}{ Humpsore } & \multirow{2}{*}{$\begin{array}{c}\text { Odds Ratio } \\
(95 \% \mathrm{CI})\end{array}$} & \multirow{2}{*}{$P$ value } \\
\hline & & Present $(n=217)$ No. $(\%)$ & Absent $(n=286)$ No. $(\%)$ & & \\
\hline \multirow{8}{*}{ Breed } & Local & $186(85.7)$ & $238(83.2)$ & $4.29(0.94-19.63)$ & 0.041 \\
\hline & Red Sindhi & $15(6.9)$ & $8(2.8)$ & $10.31(1.82-58.39)$ & 0.004 \\
\hline & Sahiwal & $5(2.3)$ & $15(5.2)$ & $1.83(0.29-11.26)$ & 0.509 \\
\hline & Holstein Cross & $2(0.9)$ & $7(2.4)$ & $1.57(0.18-13.86)$ & 0.683 \\
\hline & Jersy Cross & $4(1.8)$ & $6(2.1)$ & $3.67(0.51-26.22)$ & 0.183 \\
\hline & Hariana & $2(0.9)$ & $0(0)$ & - & - \\
\hline & Pabna & $1(0.5)$ & $1(0.3)$ & $5.50(0.23-128.98)$ & 0.255 \\
\hline & Red Chittagong & $2(0.9)$ & $11(3.8)$ & - & - \\
\hline \multirow{4}{*}{ Class } & Heifer & $16(7.4)$ & $100(34.9)$ & - & - \\
\hline & Cow & $168(77.4)$ & $141(49.3)$ & $7.45(4.19-13.21)$ & $<0.001$ \\
\hline & Bull & $17(7.8)$ & $40(13.9)$ & $2.66(1.22-5.77)$ & 0.012 \\
\hline & Bullock & $16(7.4)$ & $5(1.7)$ & $20.00(6.43-62.19)$ & $<0.001$ \\
\hline \multirow{2}{*}{ Gender } & Male & $31(14.3)$ & $41(14.3)$ & - & - \\
\hline & Female & $186(85.7)$ & $245(85.7)$ & $1.00(0.61-1.67)$ & 0.987 \\
\hline \multirow{3}{*}{ Age } & Upto 5 yrs & $55(25.3)$ & $187(65.4)$ & - & - \\
\hline & $5-10 \mathrm{yrs}$ & $137(63.1)$ & $93(32.5)$ & $5.00(3.36-7.47)$ & $<0.001$ \\
\hline & More than $10 \mathrm{yrs}$ & $25(11.5)$ & $6(2.1)$ & $\begin{array}{c}14.17(5.53- \\
36.28)\end{array}$ & $<0.001$ \\
\hline \multicolumn{2}{|c|}{ Used for ploughing } & $119(54.8)$ & $22(7.7)$ & $14.57(8.75-24.28)$ & $<0.001$ \\
\hline \multicolumn{2}{|c|}{ Injury } & $217(100)$ & $180(62.9)$ & - & - \\
\hline
\end{tabular}




\section{Akter and others}

\section{CONCLUSION}

Humpsore or stephanofilariasis is a parasitic skin disease caused by the presence of nematodes in the skin of domestic animal. Females and young adults (5-10 years) are most affected. Lesions found mostly in neck region $(14.1 \%)$ in female $(36.97 \%)$ cows $(77.4 \%)$ of local breed $(12.72 \%)$ because of they are mostly reared in the dairy farm from where the possibility of infection via flies is very easy.

\section{REFERENCES}

1. Agrawal M C and Shah H L (1984). Stephanofilarial dermatitis in India. Veterinary Research Community 8: 93 102.

2. Baki MA (1995). Experimental transmission and pathology of humpsore (stephanofilariasis) in cattle. Ph. D. Thesis, Department of Pathology, Bangladesh Agricultural University (BAU), Mymensingh 2202, Bangladesh.

3. Bangladesh Economic Review (2014). Ministry of finance, govt. of the people's republic of Bangladesh, pp: 104-105.

4. Banglapedia (2015). Livestock National Encyclopedia Bangladesh pp:1-15.

5. Fadzil M (1977). Stephanofilaria kaeli infection in cattle in peninsular Malaysia prevalence and treatment. Veterinary Medical Review 1: 44-52.

6. Ibrahim MZU, Hashim MA and Hossain MA (2013). Comparative efficacy between surgical intervention, organophosphorus and ivermectin against humpsore (stephanofilariasis) in cattle. Journal Advanced Biomedical Pathobiologial Research 3: 100-109.

7. Johnson SJ, Arthur RJ and Shepherd RK (1986). The distribution and prevalence of stephanofilariasis in cattle in Queensland. Australian Veterinary Journal 63: 121-124.

8. Junquera P (2015). Stephanofilaria stilesi Parasitic roundworms of cattle. Biology, prevention and control stephanofilariasis.Parasitipedia.net.URL.http://parasitipedia.net/index.php?option=com_content\&view=article\&id= 2642\&Itemid=2920 (accessed 2.11.16).

9. Nooruddin M and Hoque MF (1985). Stephanofilariasis in cattle. Agricultural Practice 6(6): 36-39.

10. Noorudin M, Hoque MF and Islam KS (1986). Epidemiological study of stephanofilariasis in Bangladesh, International Journal of Tropical Agriculture 4: 96-98.

11. Roy S and Misra SK (1989). Incidence of stephanofilarial dermatitis in cattle in Nadia district of West Bengal. Indian Veterinary Journal 66: 111-114.

12. Roy S and Misra SK (1990). Prevalence of stephanofilariasis in domestic animals in different districts of West Bengal. Journal of Veterinary Parasitology 4: 41-43.

13. Singh KS, Mukhopadhayay SK, Majumder S, Laha R, Niyogi D and Ganguly S (2014). Study on different aspects of stephanofilarial dermatitis infection in cattle population of West Bengal 5: 19-22.

14. Subha G (2013). Biological and scientific opinion on study on the various aspects of "humpsore" in cattle population of India. A Review of Journal Biological Science Opinion 1: 98-100. 